\title{
Therapeutic Management, Genital Changes versus Blood Biochemical Constituents of Repeat Breeder Crossbred Cows
}

\author{
Lakshya Jyoti Dutta ${ }^{1 *}$, Raju Deka ${ }^{1}$, Keshab Chandra Nath ${ }^{1}$, Dipak Bhuyan ${ }^{1}$, Manjyoti Bhuyan ${ }^{1}$, \\ Manna Baruti ${ }^{1}$, Durlav Prasad Bora ${ }^{2}$ and Indrajit Gayari ${ }^{3}$ \\ ${ }^{1}$ Department of Animal Reproduction, Gynaecology \& Obstetrics, College of Veterinary Science, AAU, Khanapara, \\ Guwahati, Assam, INDIA \\ ${ }^{2}$ Department of Veterinary Microbiology, College of Veterinary Science, AAU, Khanapara, Guwahati, Assam, INDIA \\ ${ }^{3}$ Department of Animal Genetics and Breeding, College of Veterinary Science, AAU, Khanapara, Guwahati, Assam, INDIA
}

*Corresponding author: LJ Dutta; E-mail: drljdutta@gmail.com

Received: 19 June, 2020

Revised: 06 Nov., 2020

Accepted: 12 Nov., 2020

\begin{abstract}
ASBTRACT
The study was aimed to determine the genital changes, blood biochemical profile and efficacy of different treatment protocols in addressing repeat breeding in crossbred cattle with prolonged oestrus which was usually associated with ovulatory defects such as anovulation and delayed ovulation. For this a total of 48 repeat breeder cows with the history of prolonged oestrus and with apparently normal oestrual discharge were selected and divided into 4 groups and each comprising 12 animals. Various commonly used therapeutic techniques like administration of hCG drug with or without supportive treatment, multiple A.I. and supportive treatment alone was used in the present study. Efficacy of treatment was based on post treatment conception rate and found that the hormone hCG was the choice of drug for treatment of repeat breeding without uterine infection resulting in post treatment conception rate of 83.33 per cent which increased to 91.66 per cent when fortified with supportive treatment. In terms of genital changes occurring in repeat breeder cows under different treatment regimens in the present study it could be mentioned that there was no much variation between treatment regimens
\end{abstract}

\section{HIGHLIGHTS}

(0 Effect of different treatment protocols to address repeat breeding without uterine infection in crossbred cows.

(0) The hormone hCG was found to be choice of drug for treatment of repeat breeding cow without uterine infection.

Keywords: Repeat breeder, crossbred cows, conception rate, hCG

Indian dairy sector has been found to contribute a large share in gross domestic products of the country. Still increased milk production remains a challenge to the planners, researchers, clinicians and entrepreneurs concerned with dairy development in India in terms of state wise variation in per capita availability of milk.

Increased productivity in animals requires matching of genotype to production environment together with appropriate husbandry practices such as nutrition, breeding and disease control. However, efficiency of reproduction is considered as the basic requirement for full expression of production potential in animals. Reproductive disorders in cows reduce their breeding efficiency making them incapable of producing a calf a year. Common reproductive disorders in cattle are repeat breeding, anoestrus, retention of placenta, dystocia and ovulatory defects which vary in occurrence with type of animal, breed, parity and level of nutrition and production. The major reproductive disorders of economic importance in cattle are repeat breeding and anoestrus which cause increase in the span of days open

How to cite this article: Dutta, L.J., Deka, R., Nath, K.C., Bhuyan, D., Bhuyan, M., Baruti, M., Bora, D.P. and Gayari, I. (2020). Therapeutic management, genital changes versus blood biochemical constituents of repeat breeder crossbred cows. J. Anim. Res., 10(6): 941-947. Source of Support: None; Conflict of Interest: None 
in cows. Increase in open span by one cycle even accounts for loss of production in addition to cost of treatment and labour involved in the vacant days.

Repeat breeders are animal cycling normally without any clinical abnormalities, but fail to conceive even after at least three successive inseminations. They have clinically normal reproductive tract, estrous cycles and estrus periods (Roberts, 1971). Repeat breeding has multifactorial etiology and hence, multidirectional approach is necessary for proper diagnosis and treatment of repeat breeding in cows. Uterine infections, Ovulation abnormalities such as anovulation and delayed ovulation, luteal insufficiency are the common causes for repeat breeding in cattle. Repeat breeders are likely to have delayed ovulation and an extended follicular phase which allows follicle development but postpones the Luteinizing hormone (LH) surge (Noakes, 2009).

The delayed LH surge produces relatively aged follicles and oocytes by the time of ovulation. Mihai and Jospe (2017) recorded the two main reasons of repeat breeding syndrome were the management factor (timing of insemination) and cow factor (ovulatory failure and hormonal imbalance). Different therapeutic techniques are in practice for management of reproductive disorders in animals. These include hormones, antibiotics, antiseptics, immunomodulators and both macro and micro elements being administered through different routes. Common drugs being used for treatment of repeat breeding without uterine infection in cattle are administration of $\mathrm{GnRH}$ or hCG at the time of insemination favours LH surge, which results in improved pregnancy rate (Methwe et al., 2013).

However, response to Parikh et al. (2018) reported that GnRH and hCG may serve as an excellent tool for improvement of pregnancy rate in repeat breeder Gir cows based on conception rate. However, success rates of these treatment regimens in terms of post treatment conception rates in the affected animals have been found to vary in wider range.

Hence, the present investigation was conducted to study the genital changes, blood biochemical profile and therapeutic management of repeat breeding crossbred cows without uterine infection through hormonal and physio-nutritional interventions under field conditions of Assam, India.

\section{MATERIALS AND METHODS}

\section{Ethical approval}

The procedure performed in this study was ethically approved by Institutional Animal Ethics Committee (IAEC) and approval number 770/ac/CPCSEA/FVSc/ AAU/IAEC/15-16/291 dated 10/04/2015.

\section{Selection of animals}

For this a total of 48 repeat breeder crossbred cows from different private farms of Asaam with the history of prolonged oestrus (more than 2 days), fail to conceive even after three consecutive inseminations showed apparently normal oestrual discharge were selected and divided into 4 groups and each comprising 12 animals. Oestrus was considered to be prolonged when the cow was reported to have more than 48 hours oestrus duration.

\section{Application of therapeutic techniques}

This experiment was conducted to study the efficacy of different treatment protocols in addressing repeat breeding in cattle with prolonged oestrus which was usually associated with ovulatory defects such as anovulation and delayed ovulation. The choice of drug was hCG (Chorulon, human chorionic gonadotrophin as a white freeze dried crystalline powder, MSD-Animal Health, Pune, India) with or without supportive treatment. Efficacy of multiple A.I. and supportive treatment alone was also studied. For this a total of 48 repeat breeder cows with the history of prolonged oestrus and with apparently normal oestrual discharge were selected and divided into 4 groups and each comprising 12 animals.

All the cows were treated with Levofloxacin (Lenovo A.P. $60 \mathrm{ml}$ ) intrauterine daily for 3 days to rule out sub-clinical uterine infections.

The animals were treated in the subsequent oestrus as per the following plan.

Group I. Multiple Artificial Insemination: In this group each animal was inseminated on $2^{\text {nd }}$ and $3^{\text {rd }}$ day of oestrus. If felt a third insemination was done on $4^{\text {th }}$ day.

Group II. Supportive treatment: In this group the animals were inseminated on $2^{\text {nd }}$ day of oestrus and 
given supportive treatment which was started from day of oestrus comprising of bypass fat, minerals and vitamins as described below:

1. Bypass Fat (Fatomax, Intas Pharmaceuticals limited, Ahmedabad, India)@150 gm/ day/ animal for 20 days.

2. Mineral mixture (Minfa Gold, Intas Pharmaceuticals limited, Ahmedabad, India)@30 gm/day/ animal for 30 days.

3. Injectable Phosphorus (Tonophosphan Vet, containing sodium salt of 4-dimethyl amino-2-methyl phenylphosphinic acid, MSD-Animal Health, Pune, India) (a) 2 gm intramuscularly per day for three occasions at alternate days.

4. Vitamin A (Intavita H, Intas Pharmaceuticals limited, Ahmedabad,India)@5ml intramuscularly for three occasions at alternate days.

Group III. hCG: Each cow under this group was administered with hCG 3000 I. U. intravenously just after A.I. done on $2^{\text {nd }}$ day of oestrus.

Group IV. hCG + Supportive: hCG 3000 I. U. intravenously just after A.I. on $2^{\text {nd }}$ day of oestrus + supportive treatment as mentioned in Group II.

\section{Clinico-gynaecological examination}

All the experimental animals under this trial were examined per rectum on day 0 or on the day of oestrus (before treatment), day 14 (after treatment) and day of subsequent oestrus following treatment. On each day of examination characteristics of vaginal discharge, uterine tone and presence of ovarian structures viz. palpable follicle and palpable corpus luteum (CL) were recorded and compared between groups.

\section{Blood Biochemical constituents}

Blood samples from jugular vein were collected on day 0 (on the day of oestrus) and day 14 of treatment. The serum was separated by centrifugation method and stored at -20 degree centigrade for further analysis.

The Blood biochemical constituents like calcium (Ca) using Liquizyme Calcium Test Kit (Beacon Diagnostics Private Limited, India), phosphorus (P) using Phosphorus
Monotest UV method (Greiner Diagnostic GmBH, Germany), iron (Fe) using Iron-NP kit (Greiner Diagnostic $\mathrm{GmBH}$, Germany) and zinc (Zn) using Zinc -NP kit (Greiner Diagnostic GmBH, Germany) were estimated by colorimetric method as per manufacturers' instructions. ELISA technique was employed to estimate the serum oestrogen (Estradiol ELISA kit, LDN, Germany) and progesterone (Progesterone ELISA kit, LDN, Germany) level in the collected samples. Metabolic hormones like leptin, ghrelin and insulin like growth factor-I (IGF-I) were estimated by using ELISA kit (Cloud Clone Corpn., USA) following manufacturers' instructions.

\section{STATISTICAL ANALYSIS}

The statistical analysis of the data was done using software IBM-SPSS-20 (http://www.spss.co.in) and Micro Soft Excel-2010 (http: //office. microsoft.com).

\section{RESULTS AND DISCUSSION}

\section{Post treatment conception rate in repeat breeder cows not associated without uterine infection}

Results obtained in the present study indicated that hCG was the choice of drug for treatment of repeat breeding in cows not associated with uterine infection resulting in 83.33 per cent post treatment conception rate. The post treatment conception rate was enhanced up to 91.66 per cent when hCG treatment regimen was fortified with supportive treatment. Multiple A.I. was not found to be effective in the management of repeat breeding without uterine infection which resulted in only 33.33 per cent conception rate. On the other hand, supportive treatment resulted in 50.00 per cent conception rate in repeat breeder cows. Other reports on the use of hCG for treatment of repeat breeding in cattle indicated wide variation in the post treatment conception rate. Deka (1994); Borah (2002); Pandey et al. (2016) using 3000 I.U. hCG intravenously for treatment of repeat breeding in crossbred cows obtained post treatment conception rate ranging from 60.00 to 75.00 per cent which was lower than the conception rate obtained in the present study. Further lower conception rate (50.00 per cent) obtained using 1500 I.U. of hCG for treatment of repeat breeding in cattle had been reported by Mathew et al. (2013) and Kumar et al. (2014). On the other hand Mehta et al. (1986); Parmar et al. (2016) could 
get 83.33 per cent repeat breeder cows pregnant following treatment with hCG. This was similar to the post treatment conception rate observed in the present study (83.33 per cent) using 3000 I.U. hCG intravenously, but lower than the post treatment conception rate obtained by fortification of hCG with supportive treatment (91.67 per cent). The above mentioned data also supported the view that there was need of fortification of hCG treatment with supportive drugs for resolving the problem of repeat breeding in cattle with full success. Multiple A.I. was not effective for addressing repeat breeding in cattle. Kantharaj et al. (2015) however, reported significant improvement in conception rate in repeat breeder cows using multiple A.I. but the conception rates reported were very low (18.18 per cent for single A.I. and 27.27 per cent for multiple A.I.).

\section{Characteristic genital changes in treated cows}

Frequency of occurrence of genital changes at day 0, day 14 and day of post treatment oestrus in repeat breeder crossbred cows without uterine infection and treated with multiple A. I., supportive treatment, hCG and hCG+ supportive treatment is presented in Table 2.
As regards to genital changes occurring in repeat breeder cows under different treatment regimens in the present study it could be mentioned that there was no much variation between treatment regimens in the frequency of occurrence of different types of vaginal discharge, uterine tone and palpable ovarian structures at day 0 , day 14 and day of post treatment oestrus. Therefore, it was difficult to comment on the comparative efficacy of different therapeutic techniques based on genital changes following treatment.

Table 1: Post treatment conception rate in repeat breeder cross bred cows without uterine infection treated with different treatment regimen

\begin{tabular}{llll}
\hline $\begin{array}{l}\text { Treatment } \\
\text { Regimen }\end{array}$ & $\begin{array}{l}\text { No. of animal } \\
\text { treated }\end{array}$ & $\begin{array}{l}\text { No of animal } \\
\text { conceived }\end{array}$ & $\begin{array}{l}\text { Conception } \\
\text { rate (\%) }\end{array}$ \\
\hline Multiple A. I. & 12 & 4 & 33.33 \\
Supportive & 12 & 6 & 50.00 \\
hCG & 12 & 10 & 83.33 \\
hCG + & 12 & 11 & 91.66 \\
Supportive & & & \\
\hline
\end{tabular}

Table 2: Characteristics of vaginal discharge, uterine tone and presence of ovarian structures in repeat breeder crossbred cows without uterine infection at different days of treatment with different treatment regimens

\begin{tabular}{|c|c|c|c|c|c|c|c|c|c|c|c|c|}
\hline \multirow{3}{*}{$\begin{array}{l}\text { Characteristic } \\
\text { changes }\end{array}$} & \multicolumn{12}{|c|}{ Frequency of occurence (\%) } \\
\hline & \multicolumn{3}{|c|}{ Multiple A.I. $(n=12)$} & \multicolumn{3}{|c|}{ Supportive(n=12) } & \multicolumn{3}{|c|}{ hCG(n=12) } & \multicolumn{3}{|c|}{ hCG+Supportive $(n=12)$} \\
\hline & Day 0 & Day 14 & $\begin{array}{l}\text { Post } \\
\text { treatment } \\
\text { oestrus }\end{array}$ & Day 0 & Day 14 & $\begin{array}{l}\text { Post } \\
\text { treatment } \\
\text { oestrus }\end{array}$ & Day 0 & Day 14 & $\begin{array}{l}\text { Post } \\
\text { treatment } \\
\text { oestrus }\end{array}$ & Day 0 & Day 14 & $\begin{array}{l}\text { Post } \\
\text { treatment } \\
\text { oestrus }\end{array}$ \\
\hline \multicolumn{13}{|l|}{ Vaginal discharge } \\
\hline Normal & $\begin{array}{l}100.00 \\
(12)\end{array}$ & $0.00(0)$ & $83.33(10)$ & $66.66(8)$ & $0.00(0)$ & $83.33(10)$ & $\begin{array}{l}100.00 \\
(12)\end{array}$ & $0.00(0)$ & $83.33(10)$ & $\begin{array}{l}83.33 \\
(10)\end{array}$ & $0.00(0)$ & $100.00(12)$ \\
\hline Mucopurulent & $0.00(0)$ & $0.00(0)$ & $0.00(0)$ & $0.00(0)$ & $0.00(0)$ & $0.00(0)$ & $0.00(0)$ & $0.00(0)$ & $0.00(0)$ & $0.00(0)$ & $0.00(0)$ & $0.00(0)$ \\
\hline Absent & $0.00(0)$ & $\begin{array}{l}100.00 \\
(6) \\
\end{array}$ & $16.66(2)$ & $33.33(4)$ & $100.00(12)$ & $16.66(2)$ & $0.00(0)$ & $\begin{array}{l}100.00 \\
(12)\end{array}$ & $16.66(2)$ & $16.66(2)$ & $\begin{array}{l}100.00 \\
(12)\end{array}$ & $0.00(0)$ \\
\hline \multicolumn{13}{|l|}{ Uterine tone } \\
\hline Good & $50.00(6)$ & $0.00(0)$ & $16.66(2)$ & $16.66(2$ & $0.00(0)$ & $50.00(6)$ & $33.33(4)$ & $0.00(0)$ & $83.33(10)$ & $50.00(6)$ & $0.00(0)$ & $66.66(8)$ \\
\hline Moderate & $50.00(6)$ & $0.00(0)$ & $83.33(10)$ & $83.33(10)$ & $0.00(0)$ & $50.00(6)$ & $50.00(6)$ & $0.00(0)$ & $16.66(2)$ & $50.00(6)$ & $0.00(0)$ & $33.33(4)$ \\
\hline Absent & $0.00(0)$ & $\begin{array}{l}100.00 \\
(12)\end{array}$ & $0.00(0)$ & $0.00(0)$ & $100.00(12)$ & $0.00(0)$ & $16.66(2)$ & $\begin{array}{l}100.00 \\
(12)\end{array}$ & $0.00(0)$ & $0.00(0)$ & $\begin{array}{l}100.00 \\
(12)\end{array}$ & $0.00(0)$ \\
\hline \multicolumn{13}{|l|}{ Ovarian structure } \\
\hline Palpable follicles & $\begin{array}{l}100.00 \\
(12)\end{array}$ & $\begin{array}{l}50.00 \\
(6)\end{array}$ & $100.00(12)$ & $\begin{array}{l}100.00 \\
(12)\end{array}$ & $100.00(12)$ & $\begin{array}{l}100.00 \\
(12)\end{array}$ & $\begin{array}{l}100.00 \\
(12)\end{array}$ & $50.00(6)$ & $\begin{array}{l}100.00 \\
(12)\end{array}$ & $\begin{array}{l}100.00 \\
(12)\end{array}$ & $\begin{array}{l}33.33 \\
(4)\end{array}$ & $100.00(12)$ \\
\hline Palpable CL & $0.00(0)$ & $\begin{array}{l}100.00 \\
(12) \\
\end{array}$ & $0.00(0)$ & $0.00(0)$ & $100.00(12)$ & $0.00(0)$ & $0.00(0)$ & $\begin{array}{l}100.00 \\
(12) \\
\end{array}$ & $0.00(0)$ & $0.00(0)$ & $\begin{array}{l}100.00 \\
(12) \\
\end{array}$ & $0.00(0)$ \\
\hline
\end{tabular}

Figure the parentheses indicate number of observations. 


\section{Blood biochemical constituents}

This part of study reveals the blood level of minerals, ovarian hormones and metabolic hormones in repeat breeder crossbred cows without uterine infection at day 0 and day 14 of treatment with different treatment regimen.

Average levels of calcium, phosphorus, iron and zinc in repeat breeder crossbred cows without uterine infection before (day 0 ) and 14 days after treatment with different treatment regimen have been presented in Table 3 and values for serum oestrogen, progesterone, leptin, ghrelin and IGF-1 are shown in Table 4.

As regards to level of blood biochemical constituents in the repeat breeder cows not associated with uterine infection it could be mentioned that out of the minerals, level of serum calcium, phosphorus and iron varied significantly between treatment regimens. It was observed that mean level of serum calcium, phosphorus and iron varied significantly between treatment regimens even before treatment which indicated existence of individual variations among the animals. Therefore, it was considered that comparison of efficacy of different treatment regimen based on serum level of the above mentioned minerals would not be fully effective. Out of the minerals only serum phosphorus and serum zinc level differed significantly between treatment days. Level of phosphorus was found to increase by day 14 of treatment in cows treated with supportive, hCG and $\mathrm{hCG}+$ supportive treatment. The mean values for serum phosphorus recorded before treatment ranged from $1.86 \pm 0.17 \mathrm{mg} / \mathrm{dl}$ in cows treated with multiple A.I. to $3.03 \pm 0.29 \mathrm{mg} / \mathrm{dl}$ in cows treated with hCG supportive treatment and their levels were far below the level given for normal cyclic cows which ranged from 5.13 to $8.03 \mathrm{mg} \%$ (Agarwal et al., 1985; Khan and Ayer, 1993; Ramakrishna, 1997; Dutta, 1999).

Table 3: Level of calcium, phosphorus, iron and zinc in the serum of repeat breeder cross bred cows without uterine infection at different days of treatment with different treatment regimen

\begin{tabular}{|c|c|c|c|c|c|c|c|c|}
\hline \multirow{3}{*}{$\begin{array}{l}\text { Treatment } \\
\text { Regimen }\end{array}$} & \multicolumn{2}{|c|}{ Calcium (mg/dl) } & \multicolumn{2}{|c|}{ Phosphorus (d/ml) } & \multicolumn{2}{|c|}{ Iron $(\mu \mathrm{g} / \mathrm{dl})$} & \multicolumn{2}{|c|}{$\operatorname{Zinc}(\mu \mathrm{g} / \mathrm{dl})$} \\
\hline & Day 0 & Day 14 & Day 0 & Day 14 & Day 0 & Day 14 & Day 0 & Day 14 \\
\hline & Mean \pm S.E. & Mean \pm S.E. & Mean \pm S.E. & Mean \pm S.E. & Mean \pm S.E. & Mean \pm S.E. & Mean \pm S.E. & Mean \pm S.E. \\
\hline Multiple A. I. & $9.58^{\mathrm{a}} \pm 0.96$ & $9.68^{\mathrm{a}} \pm 0.55$ & $1.86^{\mathrm{a}}{ }_{\mathrm{A}} \pm 0.17$ & $1.90^{\mathrm{a}}{ }_{\mathrm{A}} \pm 0.12$ & $192.60^{\mathrm{a}} \pm 12.80$ & $194.80^{\mathrm{a}} \pm 6.46$ & $103.70_{\mathrm{A}} \pm 3.51$ & $81.53_{\mathrm{A}} \pm 7.00$ \\
\hline Supportive & $12.30^{\mathrm{bc}} \pm 0.99$ & $13.40^{\mathrm{b}} \pm 0.39$ & $2.35^{\mathrm{a}}{ }_{\mathrm{A}} \pm 0.08$ & $3.02^{\mathrm{b}}{ }_{\mathrm{B}} \pm 0.47$ & $290.80^{\mathrm{b}} \pm 13.90$ & $310.40^{\mathrm{b}} \pm 15.70$ & $104.40_{\mathrm{A}} \pm 9.19$ & $70.77_{\mathrm{B}} \pm 13.90$ \\
\hline Hcg & $14.10^{c} \pm 0.92$ & $11.50^{\mathrm{ab}} \pm 1.21$ & $2.21^{\mathrm{a}}{ }_{\mathrm{A}} \pm 0.09$ & $2.77^{\mathrm{a}}{ }_{\mathrm{B}} \pm 0.25$ & $301.60^{b} \pm 32.40$ & $345.90^{c} \pm 10.60$ & $108.30_{\mathrm{A}} \pm 7.57$ & $101.70_{\mathrm{A}} \pm 20.20$ \\
\hline hCG + Supportive & $11.70^{\mathrm{ab}} \pm 1.91$ & $11.50^{\mathrm{ab}} \pm 0.83$ & $3.03^{\mathrm{b}}{ }_{\mathrm{A}} \pm 0.29$ & $3.28^{\mathrm{b}}{ }_{\mathrm{B}} \pm 0.22$ & $314.50^{\mathrm{b}} \pm 15.70$ & $321.20^{\mathrm{bc}} \pm 9.91$ & $118.00_{\mathrm{A}} \pm 4.48$ & $103.20_{\mathrm{A}} \pm 22.10$ \\
\hline
\end{tabular}

Means bearing similar superscript of small letter in a column and similar subscript of capital letter in a row within a specific blood biochemical constituent do not differ significantly.

Table 4: Level of oestrogen, progesterone, leptin, ghrelin and igf-1 in the serum of repeat breeder cross bred cows without uterine infection at different days of treatment with different treatment regimen

\begin{tabular}{|c|c|c|c|c|c|c|c|c|c|c|}
\hline \multirow{3}{*}{$\begin{array}{l}\text { Treatment } \\
\text { Regimen }\end{array}$} & \multicolumn{2}{|c|}{ Oestrogen $(\mathrm{pg} / \mathrm{ml})$} & \multicolumn{2}{|c|}{ Progesterone (ng/ml) } & \multicolumn{2}{|c|}{ Leptin(ng/ml) } & \multicolumn{2}{|c|}{ Ghrelin(pg/ml) } & \multicolumn{2}{|c|}{ IGF-1(ng/ml) } \\
\hline & Day 0 & Day 14 & Day 0 & Day 14 & Day 0 & Day 14 & Day 0 & Day 14 & Day 0 & Day 14 \\
\hline & Mean \pm S.E. & Mean & Mean & Mear & Mean & Mean & Mean \pm S.E. & Mean \pm S.E. & Mean \pm S.E. & Mean \pm S.E. \\
\hline Multiple A. I. & $\begin{array}{l}12.56_{\mathrm{A}} \pm \\
2.23\end{array}$ & $5.33_{\mathrm{B}} \pm 3.81$ & $1.66_{A} \pm 0.52$ & $9.52_{\mathrm{B}} \pm 0.26$ & $1.58^{\mathrm{a}} \pm 0.79$ & $2.62^{\mathrm{a}} \pm 0.66$ & $\begin{array}{l}912.20 \pm \\
64.70\end{array}$ & $\begin{array}{l}672.60 \pm \\
84.40\end{array}$ & $\begin{array}{l}25.49^{\mathrm{ab}}{ }_{\mathrm{A}}^{ \pm} \\
10.40\end{array}$ & $\begin{array}{l}31.75^{\mathrm{a}}{ }_{\mathrm{A}}^{ \pm} \\
2.66\end{array}$ \\
\hline Supportive & $\begin{array}{l}10.40_{\mathrm{A}} \pm \\
0.14\end{array}$ & $3.66_{\mathrm{B}} \pm 2.66$ & $3.99_{\mathrm{A}} \pm 1.58$ & $7.42_{\mathrm{A}} \pm 0.78$ & $3.16^{\mathrm{b}} \pm 1.49$ & $3.27^{\mathrm{a}} \pm 1.01$ & $\begin{array}{l}399.70 \pm \\
57.90\end{array}$ & $\begin{array}{l}1014.00 \pm \\
69.30\end{array}$ & $\begin{array}{l}38.91^{\mathrm{C}}{ }_{\mathrm{A}} \pm \\
15.00\end{array}$ & $\begin{array}{l}42.67^{\mathrm{b}}{ }_{\mathrm{A}}^{ \pm} \\
4.76\end{array}$ \\
\hline $\mathrm{hCG}$ & $\begin{array}{l}15.03_{\mathrm{A}}^{ \pm} \\
4.80\end{array}$ & $5.23_{\mathrm{B}} \pm 2.41$ & $0.78_{\mathrm{A}} \pm 0.81$ & $8.83_{\mathrm{B}} \pm 0.39$ & $3.14^{\mathrm{b}} \pm 0.97$ & $2.18^{\mathrm{a}} \pm 0.14$ & $\begin{array}{l}281.90 \pm \\
74.10\end{array}$ & $\begin{array}{l}200.10 \pm \\
20.30\end{array}$ & $\begin{array}{l}20.15^{\mathrm{a}}{ }_{\mathrm{A}}^{ \pm} \\
11.20\end{array}$ & $\begin{array}{l}33.72^{\mathrm{ab}}{ }_{\mathrm{B}} \pm \\
5.01\end{array}$ \\
\hline $\begin{array}{l}\text { hCG }+ \\
\text { Supportive }\end{array}$ & $\begin{array}{l}12.62_{\mathrm{A}} \pm \\
1.32\end{array}$ & $3.24_{\mathrm{B}} \pm 0.36$ & $1.20_{\mathrm{A}} \pm 0.17$ & $\begin{array}{l}12.90_{\mathrm{B}} \pm \\
3.58\end{array}$ & $3.49^{b} \pm 0.91$ & $5.45^{\mathrm{b}} \pm 1.06$ & $\begin{array}{l}349.90 \pm \\
30.50\end{array}$ & $\begin{array}{l}564.40 \pm \\
76.30\end{array}$ & $\begin{array}{l}33.40^{\mathrm{bc}}{ }_{\mathrm{A}}^{ \pm} \\
5.70\end{array}$ & $\begin{array}{l}40.68^{\mathrm{ab}}{ }_{\mathrm{A}} \pm \\
10.90\end{array}$ \\
\hline
\end{tabular}

Means bearing similar superscript of small letter in a column and similar subscript of capital letter in a row within a specific blood biochemical constituent do not differ significantly. 
Level of zinc decreased by day 14 of treatment and this decrease was significant only in case of cows treated with supportive treatment. In the present study it was not possible to comment on the decrease in the level of serum zinc following treatment with supportive drugs. The level of serum zinc recorded before treatment $(104.40 \pm 9.19 \mu \mathrm{g} /$ dl) was far below the level given for normal cyclic cows ranging from 172.10 to $314.00 \mu \mathrm{g} / \mathrm{dl}$ (Pradhan et al., 1995; Saxena and Gupta, 1995; Das et al., 2002; Barui et al., 2015). It was further reported that serum zinc level was comparatively low in cows affected with repeat breeding as compared to that in normal cyclic cows.

As regards to the variation in the levels of reproductive hormones it could be mentioned that serum oestrogen decreased and serum progesterone increased significantly on 14 day of treatment and this pattern of variation was observed in all repeat breeder cows under different treatment regimens. This might be attributed to the difference in stage of the oestrous cycle, day 0 of treatment falling on oestrus and day 14 on dioestrus. Mean concentration of progesterone in normal cyclic cows as $11.96 \pm 2.65 \mathrm{nM} / \mathrm{L}$ respectively as recorded by Pariza et al. (2013).

Energy level in animals had been found to be an important factor determining level of fertility in them (Bindari et al., 2013). Concentrations of metabolic hormones like leptin and ghrelin in serum have been effectively used for measuring energy balance in dairy animals. Blood levels of leptin and ghrelin were found to be sensitive indicators of energy balance. Higher level of serum leptin and lower level of serum ghrelin indicated positive energy balance (Nowroozi-Asl et al., 2016). Beam and Butler (1999) observed that higher concentration of IGF was associated with body condition score. Higher IGF concentration was also associated with nutrient intake as reported by Thissen et al. (1994). Kadivar et al. (2012) reported high IGF concentration was the main factor associated with better reproductive performance in animals. Out of the metabolic hormones only leptin and IGF-1 level varied significantly between treatment regimens. Serum leptin level recorded on 14 day of treatment was significantly higher in repeat breeder animal treated with hCG + supportive treatment while that of IGF-1 was higher in animals treated with supportive and $\mathrm{hCG}^{+}$supportive treated animals. The normal leptin level in cyclic cow was $5.12 \pm 0.43 \mathrm{mg} / \mathrm{dl}$ as reported by Guzel and Tanriverdi (2014); which is lower in the present study. Saleh et al. (2011) reported normal IGF-1 level in cyclic animals as $53.16 \pm 1.41 \mathrm{ng} / \mathrm{ml}$ which is lower in the entire group of the present study. Variation due to treatment was found significant only in case of IGF1 and was found to increase significantly after 14 day of treatment

\section{CONCLUSION}

The hormone hCG was the choice of drug for treatment of repeat breeding without uterine infection resulting in post treatment conception rate of 83.33 per cent which increased to 91.66 per cent when fortified with supportive treatment. In terms of genital changes occurring in repeat breeder cows under different treatment regimens in the present study it could be mentioned that there was no much variation between treatment regimens As regards to blood biochemical constituents it can be concluded that the serum levels of metabolic hormones might not be suitable indicators for comparison of efficacy of therapeutic techniques used for addressing repeat breeding in crossbred cattle of Assam.

\section{ACKNOWLEDGMENTS}

The authors thankfully acknowledge to Dr. B.C. Deka, Professor and Head, Department of Animal Reproduction, Gynaecology \& Obstetrics, College of Veterinary Science, Khanapara, Assam, India for his guidance and support to carry out this study.

\section{REFERENCES}

Agarwal, S.K., Pandey, N.N. and Shanker, U. 1985. Serum protein, inorganic phosphorus and blood glucose in relation to different phases of reproduction in crossbred cattle. Ind. J. Anim. Reprod., 6: 23-25.

Barui, A., Batabyal, S., Ghosh, S., Saha, D. and Chattopadhyay, S. 2015. Plasma mineral profiles and hormonal activities of normal cycling and repeat breeding crossbred cows: A comparative study. Vet. World, 8: 42-45.

Beam, S.W. and Butler, W.R. 1999. Effects of energy balance on follicular development and first ovulation in postpartum dairy cows. J. Reprod. Fertil. Suppl., 54: 411-24.

Bindari, Y.R., Shrestha, S., Shrestha, N., Gairie, T.N. 2013. Effect of nutrition on reproduction- a review. Adv. Appl. Sci. Res., 4: 421-429. 
Borah, P. 2002. Certain aspects of reproduction in Holstein Friesian and Sahiwal cross cows. M.V.Sc. Thesis, Assam Agricultural University, Jorhat.

Das, S., Bandopadhya, S. K., Basu, S., Ghosh, B.B. and Dattagupta, R. 2002. Blood mineral profile of normal cyclic and repeat breeder crossbred cows under rural condition. Ind. J. Anim. Reprod., 23: 167-169.

Deka, K.C. 1994. Studies on certain aspect of ovulatory disturbances in repeat breeding crossbred cattle. PhD Thesis, Assam Agricultural University, Jorhat.

Dutta, M. 1999. Studies on certain minerals in the blood serum and cervico-vaginal mucus of repeat breeding crossbred cows at oestrus. M.V.Sc. Thesis, Assam Agricultural University, Jorhat.

Guzel, S. and Tanriverdi, M. 2014. Comparison of serum leptin, glucose, total cholesterol and total protein levels in fertile and repeat breeder cows. Revista Brasileira de Zootecnia, 43: 643-647.

Kadivar, A., Ahmadi, M.R. and Gheisari, H.R. 2012. Assessment of $I G F-I$ as a factor influencing postpartum reproductive performance and ovarian condition in dairy cattle. Comparative Clinical Pathology, 21: 589-596.

Kantharaj, S., Chandrashekara M. V., Honnappagol, S.S., Kumar, V.G., Ramachandra, S.G. and Lakshmikanth T.R. 2015. Conception rate in repeat breeder cows following multiple artificial inseminations during spontaneous estrus. I J A P S A., 1: 32-36.

Khan, J.R. and Iyer, V.J. 1993. Comparative studies of inorganic phosphorus and magnesium levels in regular and repeat breeding cows. Indian. Vet. J., 70: 675-676.

Kumar, M., Pant, S.S., Ramsharan, R., Kumar S. and Gupta, P.K. 2014.Therapeutic efficacy of levofloxacin along with vitamin A for the management of repeat breeding syndrome in cow under field condition. Intl. J. Vet. Sci., 3: 155-157.

Mathew, R., Aravinda, M., Ghosh, K.N., Kurien, M.O. and Harshan, H.M. 2013. Comparison of human placental extract, hCG and GnRH Analogue on fertility of repeat breeding cattle. Ind. Vet. J., 90: 57-59.

Mehta, G.B., Bhavsar, B.K. and Kodagoli, S.B. 1986. Ovulatory disturbances in repeat breeding crossbred cattle. Ind. J. Anim. Reprod., 7: 63-65.

Mihai, C. and Jospe, E. 2017. Management of repeat breeding syndrome in cows. Bull. UASVM Vet. Med., 74(2): 207-211.

Noakes, D.E. 2009. Endogenous and exogenous control of ovarian cyclicty. In: Veterinary Reproduction and Obstetrics, nineth ed. Eds Noakes DE, Parkinson TJ, Gary CW. England. Saunders Elsevier, Edinburg, London New York Oxford Philadelphia St. Louis Sydney Toronto, pp. 3-58.
Nowroozi-Asl, A., Aarabi, N. and Rowshan-Ghasrodashti, A. 2016. Ghrelin and its correlation with leptin, energy related metabolites and thyroidal hormones in dairy cows in transitional period. Polish J. Vet. Sci., 19(1): 197-204.

Pandey, N.K.J., Gupta, H.P., Prasad, S. and Sheetal, S.K. 2016. Plasma progesterone profile and conception rate following exogenous supplementation of gonadotropin-releasing hormone, human chorionic gonadotropin, and progesterone releasing intra-vaginal device in repeat-breeder crossbred cows. Vet. World, 9: 559-562.

Parikh S.S., Makwana, R.B., Savaliya, B.D., Patbandha T.K. and Murthy, K.S. 2018. Effect of hormonal therapy on fertility in repeat breeding Gir cows. Int. J. Curr. Microbiol. App. Sci., 7: 4952-4958.

Pariza, K.F., Alam, J., Islam, M.R., Hossain, M.M. and Awal, M.A. 2013. Investigation of hematological and biochemical profiles of anestrous zebu cows. Bangladesh J. Vet. Med., 11: 57-60.

Parmar C.P., Patel, D.M., Dhami, A.J., Hadiya, K.K., Panchal, M.T., Patel, J.A., Buhecha, K.V and Killedar, A. 2016. Efficacy of AI + hCG and Post-AI progesterone supplementation for enhancing fertility and plasma progesterone and biochemical profile in repeat breeding cows and buffaloes. Ind. J. Vet. Sci. Biotec., 11: 7984.

Pradhan, J., Mohanty, B.N., Ray, S.K.H. and Mohanty, D.N. 1995. A comparative study of haemoglobin, Copper and Zinc concentration of postpartum anoestrus cows. Ind. J. Anim. Reprod., 16: 28-31.

Ramakrishna, K.V. 1997. Comparative studies on certain Biochemical constituents of anoestrus crossbred Jersey rural cows. Ind. J. Anim. Reprod., 18: 33-35.

Roberts, S.J. 1971. Veterinary Obstetrics and Genital disease. $2^{\text {nd }}$ Edition Scientific Book Agency, Calcutta.

Saleh, N., Mahmud, E. and Waded, E. 2011. Interactions between insulin like growth factor 1, thyroid hormones and blood energy metabolites in cattle with postpartum inactive ovaries. Nat. Sci., 9: 56-63.

Saxena, M.S. and Gupta, S.K. 1995. Variations in the Plasma levels of copper and zinc in crossbred cows with early and delyed Post-partum conception. Ind. J. Anim. Reprod., 16: 25-27.

Sharma, A.R. Jindal, N., Singh and Singh, R.V. 2003. Effect of progesterone supplementation on conception rate and hormonal profile in repeat breeding buffaloes. Ind. J. Anim. Sci., 73(7): 773-774.

Thissen, J.P., Ketelslegers, J.M. and Underwood, L.E. 1994. Nutritional regulation of the insulin-like growth factors. Endocrine Rev., 15: 80-101 
